\title{
DEBATA O PRZYSZŁOŚCI ZAWODU TEUMACZA W XXI WIEKU
}

\section{Uniwersytet Łódzki, Wydział Filologiczny, 23 września 2017 r.}

\section{Uczestnicy:}

JM-C - mgr Joanna Miler-Cassino, wiceprezes Polskiego Towarzystwa Tłumaczy Przysięgłych i Specjalistycznych TEPIS

JMS - mgr Joanna Maria Spychała, prezes Polskiego Stowarzyszenia Tłumaczy Konferencyjnych

AM - prof. UAM dr hab. Aleksandra Matulewska, kierownik Zakładu Legilingwistyki Uniwersytetu Adama Mickiewicza w Poznaniu, przewodnicząca Wielkopolskiego Koła PT TEPIS

Moderatorzy:

AG - prof. UŁ dr hab. Artur Gałkowski, prodziekan ds. naukowych, projektów oraz współpracy międzynarodowej i z otoczeniem społeczno-gospodarczym, kierownik Zakładu Italianistyki Uniwersytetu Łódzkiego, przewodniczący zarządu Stowarzyszenia Italianistów Polskich

ŁJB - dr Łukasz Jan Berezowski, adiunkt w Zakładzie Italianistyki Uniwersytetu Łódzkiego, przewodniczący sekcji włoskiej tłumaczy Polskiego Towarzystwa Tłumaczy Przysięgłych i Specjalistycznych TEPIS

AG: Dzień dobry, proszę Państwa, rozpoczniemy naszą debatę. Ja, Artur Gałkowski, kierownik Zakładu Italianistyki Wydziału Filologicznego Uniwersytetu Łódzkiego wraz z panem doktorem Łukaszem Janem Berezowskim z tego samego Zakładu poprowadzimy debatę o przyszłości zawodu tłumacza w Polsce. Ta debata, jak Państwo widzą z samego tytułu, zakłada pewną przeszłość, teraźniejszość i właśnie przyszłość. O tym będziemy rozmawiać z ekspertami i ekspertkami. Mam przyjemność powitać trzy prelegentki - uczestniczki naszej debaty, to jest Panią profesor Aleksandrę Matulewską, która reprezentuje Instytut Językoznawstwa Wydziału Neofilologii Uniwersytetu im. Adama Mickiewicza w Poznaniu, dokładnie Zakład Legilingwistyki i Języków Specjalistycznych.

AM: Witam Państwa serdecznie!

AG: Witamy również Panią mgr Joannę Marię Spychałę, która reprezentuje Polskie Stowarzyszenie Tłumaczy Konferencyjnych... 
JMS: Dzień dobry!

AG: ...oraz Panią mgr Joannę Miler-Cassino, która jest wiceprezesem Polskiego Towarzystwa Tłumaczy Przysięgłych i Specjalistycznych TEPIS.

\section{JM-C: Dzień dobry Państwu!}

AG: Przejdziemy teraz do debaty. Panie odpowiedzą na pytania, które zapowiedzieliśmy już wczoraj podczas inauguracji konferencji. Naturalnie, ja przedstawię je ponownie i wyświetlimy je również na ekranie. Panie będą miały określony czas na odpowiedź oraz na ad vocem. Będą trzy pytania, które Paniom i Państwu są już znane. W rundzie czwartej debaty pytania będą pochodziły od publiczności. Pierwsze nasze pytanie dotyczy rozdzielenia kwalifikacji zawodowych tłumacza pisemnego i ustnego, takiej praktycznej konieczności wymuszonej odrębnością metodologiczną i zapotrzebowaniem rynku tudzież dążeniem do wewnętrznej separacji środowiska zawodowego tłumaczy - czy jest to możliwe i w jakim zakresie? Jako pierwszą poproszę o odpowiedź na to pytanie Panią profesor Aleksandrę Matulewską.

AM: Szanowni Państwo, wydaje się, że dążenie do rozdzielenia kwalifikacji zawodowych w pewnym sensie jest uwarunkowane przede wszystkim naszymi predyspozycjami. Badania w zakresie tłumaczenia wykazują, że mamy świetnych tłumaczy pisemnych, którzy nie potrafią tłumaczyć ustnie i odwrotnie: mamy świetnych tłumaczy ustnych, którzy nie potrafią pracować z tekstem pisanym. Na podstawie mojego 15-letniego doświadczenia dydaktycznego mogę przede wszystkim stwierdzić, że trafiali się nam studenci, i byli to studenci znajdujący się w grupie absolutnie najlepszych jeżeli chodzi o wyniki uzyskiwane z tłumaczenia pisemnego, którzy z wielu względów niestety nie mieli predyspozycji do tłumaczenia ustnego, chociażby dlatego, że mieli różnego rodzaju zaburzenia słuchu; były to niekiedy osoby niedosłyszące z aparatami słuchowymi i chociażby z tego powodu natura uniemożliwiała im nawet próbowanie, by kształcić się w zawodzie tłumacza ustnego. Natomiast wyniki, które uzyskiwali na zajęciach $\mathrm{z}$ tłumaczenia pisemnego w porównaniu z innymi studentami były zdecydowanie dużo wyższe. Co więcej, zwraca się uwagę w środowisku tłumaczy ustnych również na to, że należałoby nawet rozważyć rozdzielenie kwalifikacji zawodowych tłumaczy konsekutywnych od tłumaczy symultanicznych, ponieważ są osoby, które świetnie czują się w kabinie, natomiast obciążenie pamięci i wysłuchanie 45-minutowego referatu, który następnie trzeba przetłumaczyć konsekutywnie, jest dla nich bardzo trudne i bardzo stresujące. My, tak naprawdę, z punktu widzenia rynku mamy taki podział wdrożony w sposób naturalny. Właściwie większość osób zrzeszonych w organizacjach zawodowych, takich jak Stowarzyszenie Tłumaczy Polskich, deklaruje, czy są oni przede wszystkim 
tłumaczami pisemnymi, czy przede wszystkim tłumaczami ustnymi, czy - idąc nawet dalej - tłumaczami literatury i poezji, tłumaczami tekstów specjalistycznych. Jeżeli przejrzymy strony internetowe tłumaczy prowadzących samodzielną działalność gospodarczą, również można bardzo wyraźnie zauważyć, że wielu z nich ogranicza się wyłącznie do jednego typu tłumaczenia. Stąd, kończąc wypowiedź, właściwie jedyna kwestia, jaka pozostaje do przedyskutowania to to, czy polski ustawodawca - w przypadku tłumaczy przysięgłych - powinien dokonać rozdziału na tłumaczy przysięgłych tekstów pisemnych i tłumaczy przysięgłych słowa żywego.

AG: Dziękuję bardzo. Tę samą kwestię omówi Joanna Maria Spychała z Polskiego Stowarzyszenia Tłumaczy Konferencyjnych. Siłą rzeczy, mogą być takie stwierdzenia, które mogą wyglądać jak powtórzenie albo też będzie Pani unikać tych powtórzeń. W każdym razie przypominam, że ad vocem przewidujemy po wypowiedziach Pań.

JMS: Mimo wszystko zacznę od ad vocem, ponieważ jak najbardziej zgadzam się, że jest to w dużej mierze kwestia predyspozycji. Tłumacz pisemny i tłumacz ustny to są rodzaje działalności, które wymagają częściowo innych predyspozycji. Ale jest to także kwestia preferencji, bo są na przykład osoby, które mają predyspozycje do obu tych zawodów, ale z jakiegoś powodu wybierają tylko jeden $\mathrm{z}$ nich, ponieważ bardziej odpowiada ich temperamentowi czy wyobrażeniom dotyczącym wybrania takiej a nie innej ścieżki zawodowej. I nieprzypadkowo powiedziałam „tych zawodów”, ponieważ dla mnie tłumacz ustny i tłumacz pisemny to są tak naprawdę dwa osobne zawody o odrębnej specyfice, wymagające różnych predyspozycji i będące wynikiem różnych wyborów, mające po prostu różną specyfikę codziennej pracy i codziennych związanych z nią wyzwań. Nie oznacza to oczywiście, że nie ma osób, które łączą w sobie jedno i drugie zajęcie, oba te elementy, są świetnymi tłumaczami ustnymi i jednocześnie świetnymi tłumaczami pisemnymi, i są to zapewne osoby, które mają predyspozycje do obu tych zawodów. Trzeba jasno powiedzieć, że w przypadku tłumaczy ustnych czy tłumaczy pisemnych to są często też te same kompetencje, które są potrzebne. Pewien podzbiór kompetencji jest tutaj zbiorem wspólnym, natomiast pewne kompetencje się różnią. Polskie Stowarzyszenie Tłumaczy Konferencyjnych, które mam przyjemność reprezentować, powstało częściowo dlatego, że wychodzimy z założenia, iż tłumacz konferencyjny jest zawodem odrębnym i specyfika naszej pracy jest na tyle różna od specyfiki, ogólnie rzecz biorąc, zawodu tłumacza, że jak najbardziej zasługuje na osobną organizację i na reprezentowanie interesów tych konkretnych tłumaczy. Odwołam się do drugiej części tego pytania: czy wyodrębnianie tłumaczy ustnych z jednej strony i tłumaczy pisemnych $z$ drugiej jest dążeniem do wewnętrznej separacji środowiska zawodowego tłumaczy. Myślę, że określenie „wewnętrzna separacja 
środowiska" ma tutaj wydźwięk zdecydowanie negatywny i mogę powiedzieć z perspektywy PSTK, że naszą wolą nie jest pogłębianie separacji czy też podziału środowiska tłumaczy, tylko po prostu zaspokajanie pewnych potrzeb takiej a nie innej grupy zawodowej. Myślę, że bardzo wiele problemów, wyzwań, kwestii, chociażby związanych z funkcjonowaniem na rynku tłumaczeniowym, jest zbliżonych w przypadku różnych zawodów tłumaczeniowych, stąd bardzo ważna jest współpraca. Oczywiście osobną kwestią jest to, czy choćby ze względów organizacyjnych warto dokonać podziału zawodu tłumacza przysięgłego na tłumacza tekstów pisanych i tłumacza słowa żywego.

AG: Bardzo dziękujemy za tę wypowiedź i poprosimy o odniesienie się do tej samej kwestii Panią Joannę Miler-Cassino z Polskiego Towarzystwa Tłumaczy Przysięgłych i Specjalistycznych TEPIS.

JM-C: Trudno mi się tutaj z przedmówczyniami nie zgodzić w kwestii predyspozycji wymaganych do wykonywania zawodu tłumacza słowa żywego czy ustnego z jednej strony, a tłumacza pisemnego z drugiej. Zdecydowanie wymagane są do tego różne predyspozycje, chociaż jedna pula predyspozycji może być wspólna; jakkolwiek tą zasadniczą częścią predyspozycji tłumacza pisemnego i tłumacza słowa żywego są jednak różne cechy charakteru. Stąd rozdzielność kształcenia tłumaczy ustnych i tłumaczy pisemnych, różne ścieżki kształcenia i też różne rynki tych tłumaczy. Część tłumaczy odnajduje się świetnie na obu rynkach, ale jednak większość tłumaczy preferuje tę albo inną ścieżkę zawodową. Oba te zawody łączą de facto thumacze przysięgli, którzy, siłą rzeczy, na podstawie ustawy muszą wykonywać oba te zawody. Muszą tłumaczyć zarówno pisemnie, jak i ustnie w sądzie, choć nie tłumaczą w kabinach. Nie chciałabym również, jak moje koleżanki, mówić o separacji rynku. Staramy się jako stowarzyszenie zawsze te rynki łączyć, znajdować cechy wspólne dla wszystkich tłumaczy. Niemniej jednak wydaje nam się, że ten podział powstał w sposób naturalny, bo to tłumacze w sposób naturalny odnajdują się lepiej w tym lub w innym środowisku. I tak właśnie, jak Państwo zaobserwujecie, przez ostatnie 20 czy 30 lat powstały rynki tłumaczy ustnych i rynki tłu maczy pisemnych. Dążyliśmy do odnalezienia się na rynku tłumacza ustnego lub tłumacza pisemnego. W ten sam sposób tłumacze przysięgli dążyli do podziału zawodu, ponieważ część tłumaczy pisemnych nie odnajduje się dobrze w tłumaczeniach ustnych. Dlatego dążyliśmy do rozdzielenia naszego zawodu tłumaczy przysięgłych na tłumaczy świadczących wyłącznie usługi tłumaczenia pisemnego dla sądów, prokuratur, policji i innych organów administracji oraz na tych pracujących ustnie, do czego jednak nie doszło. Nie wiem, czy większości z Państwa jest to informacja znana, ale w tej chwili toczą się negocjacje na temat zmiany ustawy dla tłumaczy przysięgłych i tego typu postulaty również padały ze strony niektórych stowarzyszeń, w tym najstarszego stowarzyszenia istniejącego w Polsce, Stowarzyszenia 
Tłumaczy Polskich. Ale to tendencja polska, bo w Europie widzimy tendencję odwrotną, która dąży do ujednolicenia zawodu, pojawiła się nawet taka ukuta fraza: „transinterpreter” [blend od ang. translator - tłumacz pisemny i interpreter - tłumacz ustny - przyp. red.], czyli widać, że te trendy się tam odwracają: zamiast separacji zawodu dąży się do jego ujednolicenia i do połączenia z powrotem funkcji tłumacza słowa pisanego i tłumacza słowa żywego. Także to, co kiedyś nas dzieliło, teraz z powrotem zaczyna nas łączyć.

AG: Dużo stwierdzeń, które się uzupełniają, ale być może usłyszeliśmy takie, do których Panie zechciałyby się odnieść w sposób dygresyjny albo polemiczny.

AM: Obawiam się, że akurat w kwestii kwalifikacji zawodowych tłumaczy jesteśmy dosyć zgodne i trudno tutaj polemizować z tym, co od wielu lat obserwujemy na rynku. Moglibyśmy polemizować właśnie z ustawodawcą, niestety jest on tu nieobecny. Nie mamy żadnego przedstawiciela, który mógłby z nami podyskutować na temat celowości dokonania podziału na dwa zawody: tłumacza przysięgłego ustnego i tłumacza przysięgłego pisemnego, a w konsekwencji podzielenia egzaminu, co przecież umożliwiałoby osobom chcącym działać w obu zawodach podejście najpierw do jednego, a potem do drugiego i uzyskanie kwalifikacji zawodowych z obu gałęzi tego tłumaczenia.

AG: Nie mam tu tak szerokiego prawa do ad vocem, ale powiedziałbym, że ta idea "transinterpreter" jest też ciekawa w tym podziale, a jednocześnie w łączeniu tych dwóch funkcji. Pozostawiam jednak Paniom prawo do ad vocem.

MJS: Myślę, że to, iż tak bardzo się tutaj zgodziłyśmy jest też pewnym wnioskiem czy pewną obserwacją, którą możemy sformułować po tej części naszej debaty, ponieważ pokazuje to, że opinie na temat kwestii związanych z rozdziałem zawodu w środowisku tłumaczeniowym są dość jednoznaczne i to podejście, które tutaj prezentujemy, jest mocno rozpowszechnione. Także myślę, że jest to bardzo dobre oddanie stanu nastrojów w tym środowisku zawodowym, przynajmniej na chwilę obecną. Bardzo ciekawa była ta idea „transinterpretera”, to są tendencje z innych krajów, przy czym właśnie w kontekście polskim te obserwacje są, jak sądzę, dość jednoznaczne. Nie przypadkiem w ostatnich latach powstawało też wiele stowarzyszeń zajmujących się bardzo, wydawałoby się, wąskimi działkami tłumaczeń, bo przecież to nie jest tylko kwestia, czy to tłumacz ustny, czy tłumacz pisemny, ale również kwestia, czy chodzi o tłumaczenia specjalistyczne, czy na przykład tłumaczenia audiowizualne, różnych obszarów działalności, gdzie pojawia się tłumaczenie, ale to thumaczenie jest w bardzo różnej formie. 
JM-C: Ja mogę tylko dopowiedzieć, że również my przez wiele lat byliśmy właściwie za podziałem, uznając to za korzystne właśnie ze względu na te naturalne predyspozycje oraz ze względu na głosy naszych członków, którzy byli za podziałem zawodu, chcieli tego. Natomiast w tej chwili śledzimy tendencje na rynku i generalnie sami nie wiemy, w którą stronę ten rynek będzie szedł. Obserwujemy zmianę w trendach kształcenia na Zachodzie, gdzie pojawia się coraz więcej programów kształcenia łączących obie ścieżki, czyli niedzielących - tak jak kiedyś były wyłącznie szkoły przygotowujące tłumaczy ustnych konferencyjnych lub wyłącznie tłumaczy pisemnych, teraz te ścieżki są łączone i pojawia się też ścieżka zawodowa kształcąca generalnie szeroko pojętych lingwistów, czyli programy łączące kształcenie terminologów, tłumaczy słowa żywego i tłumaczy słowa pisanego, czyli ludzi zwanych „transinterpreterami”, bardzo szeroko, ogólnie rzecz biorąc lingwistów, którzy są w stanie zaoferować bardzo szeroki zakres usług. To jest nowy trend w stosunku do tego, co obserwowaliśmy w poprzednim stuleciu. Stąd nie wiemy, czy nasze pomysły podzielenia zawodu nie są już dzisiaj anachroniczne. Wstrzymujemy się dlatego z naszymi postulatami podziału zawodu, bo nie wiemy, czy to nie jest nieco spóźniony pomysł i zobaczymy, co czas przyniesie.

AM: $\mathrm{Z}$ drugiej strony jest to też związane z pojawieniem się zupełnie nowych zawodów, z którymi nie mieliśmy w ogóle do czynienia jeszcze 10-20 lat temu, dlatego że w tej chwili potrzebujemy coraz więcej specjalistów w zakresie inżynierii terminologicznej i tutaj takie bardziej wszechstronne kształcenie pozwala absolwentowi na wybranie własnej ścieżki zawodowej, która będzie odpowiadała najbardziej jego predyspozycjom i kwalifikacjom. Natomiast z całą pewnością w zakresie inżynierii terminologicznej takie wszechstronne ksztalcenie jest konieczne po to, żeby móc zaspokoić potrzeby rynku pracy w tym zakresie.

AG: Bardzo dziękuję za tę informację, istotną również z punktu widzenia pewnej terminologii dotyczącej samego obszaru translatoryki: „inżynieria terminologiczna” czy też „prakseologia terminologiczna”. Dziękuję Paniom za odpowiedzi na to pierwsze pytanie i za ad vocem również. Jak Państwo widzą, presja czasu w ogóle nie robi na Paniach wrażenia - specjalistkach od tłumaczeń, gdzie czas i struktura wypowiedzi w określonym czasie jest tak istotna. Poproszę teraz pana doktora Łukasza Jana Berezowskiego o zadanie drugiego pytania i moderowanie odpowiedzi ad vocem w tej części debaty.

ŁJB: W drugiej rundzie chcielibyśmy zapytać Panie o celowość i formę zrzeszania się tłumaczy w Polsce. Toczy się bowiem dyskusja, czy tłumacze powinni się zrzeszać, co do tego nie ma dużych wątpliwości, ale ten dylemat mają w szczególności niektórzy młodzi tłumacze, ponieważ ich oczekiwania 
wobec organizacji są bardzo różne, a pytanie właśnie co do formy jest najistotniejsze: czy powinna to zostać formuła, w której Panie zresztą funkcjonują, czyli właśnie stowarzyszenia, organizacje pożytku publicznego, czy raczej powinniśmy dążyć w kierunku stworzenia czegoś w rodzaju korporacji tłumaczy, na wzór samorządów w zawodach prawniczych, jak na przykład u adwokatów czy notariuszy. $Z$ drugiej strony pojawią się głosy świadczące o potrzebie powołania związku zawodowego (takowy jest w trakcie rejestracji). Oznaczałoby to zmianę pozycji tłumacza nie jako przedstawiciela wolnego zawodu, ale jako tłumacza-pracownika. Poproszę o odpowiedź na to pytanie panią Joannę Miler-Cassino z PT TEPIS.

JM-C: Proszę Państwa, jestem przedstawicielem TEPIS-u, stowarzyszenia tłumaczy, które istnieje 27 lat, zrzesza 800 członków, więc jesteśmy zdania, że, jak najbardziej, oczywiście warto się zrzeszać. Mieliśmy różne momenty w minionych latach, natomiast staramy się naszym członkom zapewnić jak największą wartość dodaną, pomagamy im w różnych bataliach przed sądami i z organami wymiaru sprawiedliwości. Nasi członkowie cieszą się naszym poparciem i rzeczywiście czują to poparcie, przynajmniej takie dostajemy od nich sygnały. Na przestrzeni ostatnich lat widzimy ogromną parcelację środowiska: część tłumaczy przysięgłych, bo głównie takie osoby zrzeszamy, jest ogólnie rozproszona. Część osób nie zrzesza się w ogóle, część zrzesza się w innych organizacjach, nad czym ogromnie ubolewamy, bo chcielibyśmy tworzyć silną platformę, która mogłaby być siłą nacisku na Ministerstwo Sprawiedliwości, żebyśmy mogli rzeczywiście nasze postulaty, podwyżki stawek za tłumaczenia i podwyższenie rangi naszego zawodu zrealizować. Chcielibyśmy więc stworzyć silny i zwarty samorząd zawodowy, żebyśmy mogli samostanowić o naszym zawodzie. Wtedy będziemy rzeczywiście mogli samorealizować się w taki sposób, w jaki tego chcielibyśmy, bo będąc mierną siłą, nie będziemy w stanie faktycznie nadawać tak wysokich standardów etyki zawodowej, jakie chcielibyśmy sobie stawiać. W dzisiejszych czasach rzeczywiście stowarzyszenia przeżywają pewien kryzys, chociaż mimo to powstają nowe i mają ogromne nadzieje na przyciągnięcie dużej liczby członków, więc pozostaje nam jakaś forma wspólnej federacji, wspólnego zrzeszenia się, wspólnej walki o to, żebyśmy tworzyli jakąś zwartą formę frontu, żebyśmy razem zawalczyli o wszystkich tłumaczy, ponieważ ranga tego zawodu niestety maleje, pomimo naszej dużej liczby.

ŁJB: Bardzo dziękuję. I poproszę teraz o odpowiedź na to samo pytanie Panią Joannę Marię Spychałę z PSTK.

JMS: Pytanie o celowość. Zrzeszanie się jest celowe, tak jak słusznie powiedział Pan doktor Berezowski, i nie ma wątpliwości, że ma to sens. Z tego samego założenia wychodzi PSTK, jak i wszystkie inne stowarzyszenia 
tłumaczy. Dlaczego warto się zrzeszać? Tak jak mówiłam, prezentując nasze stowarzyszenie, zrzeszanie się jest szansą współkształtowania rynku. Jeżeli my jako tłumacze nie podejmiemy działań na rzecz współkształtowania tego rynku, to zostawiamy to działanie innym podmiotom: czy to biurom thumaczeń, czy to instytucjom organizującym przetargi itd. Oczywiście to nie musi być ponura wizja, natomiast jeśli to my chcemy współkształtować rynek, to po prostu powinniśmy działać konkretnie w tej kwestii. Forma zrzeszania? W przypadku zawodu tłumacza konferencyjnego myślę, że nie ma zbyt wielu możliwości innych niż stowarzyszenia, ponieważ nie mamy tego komfortu, który mają tłumacze przysięgli, to nie jest zawód w żaden sposób regulowany. Trudno jest nawet zdefiniować, kim tak naprawdę jest tłumacz konferencyjny. To jest pytanie, które zadawaliśmy sobie wielokrotnie, zakładając stowarzyszenie i na przykład opracowując kryteria przyjmowania nowych członków do stowarzyszenia. Ostatecznie założyliśmy, że jest to stowarzyszenie, które ma zrzeszać tłumaczy konferencyjnych, a nie ogół tłumaczy ustnych i musimy móc stwierdzić jednoznacznie, na jakiej podstawie dana osoba twierdzi, że jest tłumaczem konferencyjnym: czy to jest kwestia wykształcenia, doświadczenia. Czy to doświadczenie zdobywa się na podstawie liczby godzin przepracowanych w zawodzie, czy jakieś znaczenie ma tutaj jakość tłumaczenia, czy też różnorodność kontekstów, w których pracujemy, bowiem tłumacz konferencyjny to jest dość typowy zawód wolnego strzelca. Stąd pytanie: czy bardziej tłumaczem konferencyjnym jest osoba, która tłumaczy dla wielu klientów na bardzo różnych konferencjach, czy osoba, która tłumaczy stale dla jednej i tej samej firmy. Są różne pytania, które sobie zadajemy i stwierdziliśmy, że nie ma jednej słusznej definicji tego zawodu. W związku z tym trudno jest nam zdecydować się na inne formy zrzeszenia, które z założenia mają być kierowane do osób, które posiadają pewien status zawodowy i mają jednocześnie potwierdzony fakt wykonywania tego, a nie innego zawodu. W kwestii tego, czy tłumacz to wolny strzelec, czy bardziej pracownik, w kwestii tłumaczy konferencyjnych sprawa ta jest bezprzedmiotowa: tłumacz to wyłącznie wolny strzelec, to zawód typowo dla freelancerów. Mało który klient potrzebuje tłumacza konferencyjnego na co dzień, klienci mają zwykle jedną - dwie konferencje rocznie, może trzy, w związku z tym tłumaczymy w bardzo różnych miejscach dla bardzo różnych klientów. A zatem, co do formy zrzeszania powiedziałabym, że w naszym zawodzie raczej wyłącznie jest to stowarzyszenie. Zrzeszanie się ma sens i, tak jak mówiła moja przedmówczyni, bardzo ważna jest współpraca w organizacjach zrzeszających tłumaczy. Razem możemy zrobić więcej na rzecz kształtowania rynku.

ŁJB: Bardzo dziękuję. I o odpowiedź na to samo pytanie i w tym samym trybie poprosimy Panią profesor Aleksandrę Matulewską z Uniwersytetu Adama Mickiewicza w Poznaniu. 
AM: Pozwolę sobie odnieść się do celowości zrzeszania się, ale jednak może nie z punktu widzenia tłumaczy jako grupy, ale jednostkowego tłumacza, dlatego że w zasadzie każdy, rozpoczynając kiedyś pracę w tym zawodzie, staje przed pytaniem, czy przystąpić do jakiegoś stowarzyszenia. W chwili obecnej na polskim rynku mamy wyłącznie stowarzyszenia, o związkach zawodowych na razie mówić nie możemy, bo jest to inicjatywa in statu nascendi. I jak zrzeszać się, to dlaczego warto? Przede wszystkim zawód tłumacza jest bardzo często związany z pracą nie tyle na etat $\mathrm{w}$ jakiejś jednej firmie, ale właśnie $\mathrm{z}$ wykonywaniem tej pracy na zlecenie bardzo różnych zleceniodawców, którzy nie zawsze są zleceniodawcami płacącymi za wykonaną usługę w terminie. Zwłaszcza w takich sytuacjach sam tłumacz, kiedy potrzebuje ściągnąć kwotę rzędu na przykład 350 złotych, tak naprawdę ma niewielką szansę na to, by takie pieniądze wyegzekwować. Zleceniodawca zwykle zdaje sobie sprawę z tego, że nie pójdziemy do sądu i nie zapłacimy opłaty sądowej mocno przekraczającej wysokość należności i nie uwikłamy się w długo trwające postępowanie sądowe, koszty przedstawiciela procesowego. Natomiast członkowie stowarzyszeń mają możliwość zwrócenia się właśnie do stowarzyszenia z prośbą, aby do takiego klienta wystosowało pismo. $\mathrm{W}$ momencie, gdy stowarzyszenie takie pismo wzywające do zapłacenia za wykonaną usługę napisze, wiadomo, że klient dużo szybciej reaguje. Przede wszystkim dlatego, że stowarzyszenie z zasady pewne procedury realizuje z założeń ideologicznych. Stowarzyszenie, dysponując budżetem ze składek członkowskich, ma możliwość wystąpienia na drogę prawną, nawet jeżeli kwota, która ma być ściągnięta, jest dużo niższa niż wysokość opłaty sądowej i w takich sytuacjach zazwyczaj po otrzymaniu takiego pisma zleceniodawca już nie czeka na dalsze kroki stowarzyszenia, tylko dokonuje przelewu. Ostatnio mieliśmy do czynienia z bardzo ciekawą sytuacją: tłumaczka z Wielkiej Brytanii wykonała zlecenie agencji tłumaczeniowej polskiej, która nie chciała jej zapłacić tłumacząc się, że klient, który to zlecenie złożył, jeszcze jej nie zapłacił. Tłumaczka, nie mogąc ściągnąć kwoty ok. 400 funtów brytyjskich, zwróciła się do jednego ze stowarzyszeń w Polsce o pomoc. Po wystosowaniu pisma przez polskie stowarzyszenie, w ciągu 24 godzin przelew był na koncie.

ŁJB: Dziękuję bardzo. I poprosimy teraz o ad vocem do wypowiedzi w tej rundzie. Zaczniemy ponownie od Pani Joanny Miler-Cassino.

JM-C: Stowarzyszenia pełnią właśnie podobnie funkcje nie tylko w kontaktach z biurami tłumaczeń, ale przede wszystkim z urzędami. Pomagają w kontaktach z sądami, co jest niezmiernie istotne, bo biura tłumaczeń to jedna rzecz, natomiast napisać zażalenie do referendarza, złożyć je w terminie i złożyć je w taki sposób, że referendarz go nie odrzuci, to już poważniejsza kwestia. Akurat tam potrzeba porady prawnej niejednokrotnie, a stowarzyszenia dysponują funduszami swoich członków, które pozwalają im skorzystać 
z takiej porady. Stowarzyszenia dysponują również funduszami na opinie prawne i niejednokrotnie jest tak, że rzeczywiście wyprzedzają myślenie pojedynczego tłumacza, zastanawiając się, jakie problemy mogą wystąpić w konkretnej sprawie i publikują informacje przed czasem. Krótko mówiąc: należąc do stowarzyszenia, możecie Państwo oczekiwać, że przed końcem roku otrzymacie informację typu: „Uwaga! Od przyszłego roku będziecie musieli wysyłać Jednolity Plik Kontrolny, bo jako osoby prowadzące działalność gospodarczą ta regulacja Was obejmie". Wraz z nią przychodzi cały wachlarz informacji, jak to robić, jakie problemy z tego wynikają itd. Tak więc należąc do stowarzyszenia, będziecie otrzymywać takie informacje. Dlatego właśnie, między innymi, warto się zrzeszać. Nie zrzeszając się, jako tłumacze-single na rynku musicie przez takie kruczki prawne przedzierać się na własną rękę, co zabiera czas i pieniądze, ponieważ ten czas moglibyście poświęcić na zarabianie pieniędzy, a stowarzyszenie robi to za Was. Po prostu.

\section{ŁJB: Pani Joanna Maria Spychała, prosimy ad vocem.}

JMS: Myślę, że w tej części rundy pojawiła się bardzo ciekawa perspektywa, czyli perspektywa indywidualnego tłumacza, co taka osoba zyskuje, będąc członkiem stowarzyszenia. Bardzo łatwo jest mówić o tym, że chcemy zacząć zmieniać rynek, że chcemy, żeby wszyscy się zrzeszali i że nam wszystkim ma być lepiej, ale pytanie, co ma z tego konkretna osoba? Przy tym, co słyszeliśmy do tej pory, myślę, że bardzo ważnym jest też to, że stowarzyszenia są pewną platformą komunikacji dla tłumaczy, przekazującą informacje o wydarzeniach na stronie internetowej czy poprzez newslettery, na przykład ostrzegające przed różnymi planowanymi zmianami prawnymi, czy też poprzez różne fora dyskusyjne, grupy facebookowe, narzędzia komunikacji. To jest na pewno ważne, że w ten sposób czasem łatwiej można otrzymać wsparcie od innych osób z tej samej grupy zawodowej, że jest to możliwość wymiany doświadczeń, korzystania z doświadczeń kolegów, niepopełniania tych samych błędów - co pokazuje chociażby ten przykład z kwestią ściągania należności. Dzięki różnym narzędziom komunikacji, jakim jest choćby Facebook, istnieje możliwość zapytania wcześniej, czy dany zleceniodawca jest rzetelny, czy też dzięki grupom, w których tłumacze nawzajem ostrzegają się przed nierzetelnymi, niepłacącymi kontrahentami. Jest to na pewno forma wsparcia pokazująca, że warto walczyć o swoje, o takie a nie inne warunki pracy, że konieczne jest zachowanie odpowiednich standardów, kiedy na przykład inne osoby mówią, że udało się coś wynegocjować. Zatem, moim zdaniem, kwestia zrzeszania się i tego, co tłumacze zyskują dzięki stowarzyszeniom, to też jest pytanie o chęć działania w tych stowarzyszeniach, a nie tylko o kwestię przynależności do nich. To nie jest tylko coś jednostronnego, sytuacja, w której stowarzyszenia coś tworzą i oferują innym, indywidualnym tłumaczom, ale jest to również pytanie o to, co tłumacze chcieliby razem zdziałać, 
żeby nam wszystkim było lepiej w grupie, nie tylko tym indywidualnym, bo stowarzyszenie to nie tylko zbiór indywiduów, ale przede wszystkim wspólnota.

ŁJB: Bardzo dziękuję. Na koniec tej rundy ponownie głos zabierze Pani profesor Aleksandra Matulewska.

AM: Rzeczywiście ogromną wartością dodaną jest to, że stowarzyszenia informują swoich członków o zmianach, które zachodzą w przepisach prawnych. W zeszłym roku na konferencji organizowanej przez stowarzyszenie TEPIS przedstawiciel Ministerstwa Sprawiedliwości poinformował nas o tym, że była taka bardzo poważna sprawa dyscyplinarna, dotycząca tłumaczki przysięgłej powołanej na początku lat 90 . ubiegłego wieku, która nie zorientowała się aż do 2016 r., że nie dopełniła formalności i od wielu lat nie ma już uprawnień do wykonywania zawodu właśnie dlatego, że w ogóle nie śledziła zmian w przepisach prawnych ani tego, co z tym zawodem się dzieje. Nie należała do żadnej organizacji i właściwie jak taka osamotniona, bezludna wyspa wykonywała swój zawód, niejako „na dziko”, łamiąc przy tym prawo. Co więcej, stowarzyszenia organizują również szkolenia, a dla swoich członków proponują zawsze ceny preferencyjne. Te szkolenia organizowane są też na tematy, które są interesujące dla członków. Członkowie mają prawo zgłaszania propozycji szkoleń, a stowarzyszenie stara się wtedy takie szkolenie zorganizować.

AG: Przejdziemy teraz do rundy trzeciej. Zanim staniemy się jednak tłumaczem-singlem, czy też tłumaczem stowarzyszonym, tak czy inaczej do obu tych pozycji trzeba się wcześniej przygotować. I to jest kwestia, która może nas interesować, bo jesteśmy w kontekście akademickim i chcielibyśmy zapytać Panie właśnie w tej trzeciej rundzie o formy kształcenia i specjalizacji tłumaczy na poziomie uniwersyteckim w Polsce. Oto pytanie: jak studia filologiczno-lingwistyczne, które oferują polskie uczelnie, odpowiadają oczekiwaniom rynku i przygotowują do wykonywania zawodu tłumacza versus czy tłumaczem musi być koniecznie filolog, lingwista. O odpowiedź na to pytanie poproszę jako pierwszą Panią profesor Aleksandrę Matulewską.

AM: Przede wszystkim, czy tłumaczem musi być filolog? Nie, tłumaczem nie musi być filolog. Akurat dysponuję bazą prac tłumaczeniowych wykonywanych przez słuchaczy studiów podyplomowych od roku 2003 i z analizy tych prac wynika, że kompetencje filologów i niefilologów się różnią oraz że statystycznie kwestia, jakiego rodzaju błędy są przez nich popełniane w procesie tłumaczenia, też wykazuje pewne rozbieżności. Jeżeli chodzi o filologów, prace są dużo wyższej jakości stylistycznej i gramatycznej. Ogólnie rzecz ujmując, płaszczyzna językowa filologów jest zwykle na dużo wyższym poziomie, dotyczy to także poziomu zaawansowania języka i jego wyszukania. $Z$ kolei w przypadku 
niefilologów, bardzo często prawników i ekonomistów, którzy przychodzą na studia podyplomowe, by kształcić się w zakresie tłumaczenia prawniczego, popełniają oni dużo mniej błędów, w wyniku których dochodzi do zmiany znaczenia, produkują dużo mniej tzw. nonsensów, inaczej mówiąc, błędów merytorycznych, które najczęściej mają bardzo poważne konsekwencje. Kiedy mówimy o tłumaczeniu specjalistycznym - prawniczym, ekonomicznym, medycznym, klient nie pozwie tłu macza do sądu o to, że gdzieś wyraz „który” został napisany przez „u”, a nie przez „ó", czy o to, że zgubił nam się przecinek przed „że”, natomiast w przypadku błędów prowadzących do zmiany znaczenia już te konsekwencje mogą nastąpić. Okazuje się też, że to, iż niefilolodzy stosują prostsze konstrukcje gramatyczne, nie oznacza, że popełniają błędy gramatyczne. Te przekłady potrafią być dużo wyższej jakości merytorycznej, jeżeli mówimy o zgodności znaczenia tekstu źródłowego z tekstem docelowym. Natomiast pewnym jest to, że odsetek osób z wykształceniem niefilologicznym wykonujących zawód jest zdecydowanie niższy aniżeli zapotrzebowanie rynku, w związku z czym, siłą rzeczy, jeżeli pozbawilibyśmy prawa kształcenia się filologów i próbowali zmusić prawników do tego, żeby wykonywali zawód tłumacza, to doszlibyśmy do sytuacji, w której tłumaczenia w ogóle nie byłyby wykonywane i przez to bardzo wiele osób zostałoby pozbawionych pomocy tego pośrednika w komunikacji międzyjęzykowej, co z kolei, z całą pewnością, miałoby katastrofalne skutki. Tymczasem w procesie kształcenia filologów bardzo istotną kwestią jest uświadomienie im, jak ważne jest zdobycie wiedzy pozajęzykowej z dziedziny, z której teksty chcą oni tłumaczyć, ponieważ bez tego poprawne tłumaczenie tekstów nie jest możliwe. Z kolei filolog, który taką potrzebę postrzega i podnosi swoje kwalifikacje merytoryczne, może być bardzo dobrym tłumaczem specjalistycznym.

AG: Poproszę teraz Panią Joannę Marię Spychałę o odpowiedź na to pytanie.

JMS: Czy studia filologiczno-lingwistyczne odpowiadają oczekiwaniom rynku i przygotowują do wykonywania zawodu tłumacza? Na tak szeroko postawione pytanie odpowiem: nie. Program studiów lingwistycznych czy program tradycyjnych studiów filologicznych obejmuje taką wiedzę i takie przedmioty, jak zagadnienia z zakresu literatury, językoznawstwa, kultury krajów języka docelowego, czy też na przykład historię itd. Natomiast nie są to studia, które przygotowują bezpośrednio do zawodu tłumacza, choć oczywiście nabywane kompetencje, wiedza w zawodzie tłumacza się przydaje, ponieważ pozwala, na przykład, na lepszą orientację w kulturze i oddanie tej treści w tłumaczeniu. Mówię tutaj o takich tradycyjnych studiach filologicznych i jeżeli w programie studiów pojawiają się już specjalizacje tłumaczeniowe, pojawiają się praktyczne zajęcia, które pozwalają na nabycie tych umiejętności tłumaczeniowych, to oczywiście sytuacja jest zupełnie inna i takie programy, takie studia, mają ogromny sens. To może być specjalizacja na studiach lingwistycznych, czy też mogą to być 
studia podyplomowe albo forma kształcenia będąca dłuższym, dobrze przygotowanym kursem. Takie kompetencje tłumaczeniowe bardzo się potem przydają, również te nabyte z obszaru edukacji formalnej. Natomiast czy tłumacz musi być filologiem? Zgodzę się tutaj, że nie i jest wiele przykładów osób - zwłaszcza wśród tłumaczy tekstów specjalistycznych: prawników, lekarzy, biologów czy inżynierów, którzy świetnie przekładają teksty ze swoich dziedzin i do tego mają znakomitą umiejętność rozumienia całego kontekstu, treści, znajomość terminologii, przy czym te osoby muszą mieć też kompetencje tłumaczeniowe. I stąd na przykład w ich przypadku wskazany jest wybór studiów podyplomowych, czy też połączenie dwóch kierunków: takiego tradycyjnego filologicznego z kierunkiem dającym wiedzę z określonej dziedziny. Tak więc, nie mówiłabym tutaj o tym, czy potrzebne są takie studia, które czynią z absolwenta tlumacza, ale o pewnych konkretnych kompetencjach, które w jakiś sposób można zdobyć. Czasami jest po prostu dużo łatwiej efektywnie zdobyć je w trakcie programu kształcenia, przygotowującego konkretnie do zawodu thumacza konferencyjnego czy do zawodu tekstów pisanych, więc filologia jako taka nie czyni z absolwenta tłumacza, ale może się bardzo przydać w dalszej ścieżce rozwoju zawodowego. Osoba, która z kolei nie jest filologiem, na drodze edukacji formalnej bądź nieformalnej musi nadrobić te kompetencje, które posiada filolog.

AG: I poprosimy jeszcze Panią Joannę Miler-Cassino o odpowiedź na to pytanie.

JM-C: Proszę Państwa, jako wykładowca Interdyscyplinarnego Podyplomowego Studium Kształcenia Tłumaczy przy Instytucie Lingwistyki Stosowanej Uniwersytetu Warszawskiego widzę, że przychodzą do nas głównie magistrzy, którzy chcą podejść do egzaminu na tłumacza przysięgłego, czyli w ich przypadku ścieżka kształcenia jest bardzo prawnicza albo jest to wykształcenie filologiczne plus solidna wiedza z jakiejś dziedziny, czyli samo wykształcenie filologiczne niestety nie wystarcza albo jest to wiedza dziedzinowa. To znaczy, że przychodzą do nas magistrzy chemii, inżynierowie z jakiejś dziedziny i jest im niezbędna solidna wiedza z obszaru prawa, z dziedziny metodyki przekładu i uzupełnienie tej całej wiedzy lingwistycznej, której siłą rzeczy nie mogli posiąść na swoich studiach. Bowiem sama wiedza z jakiejś dziedziny nie wystarcza, aby być tłumaczem. Czyli mamy dwie możliwości, żeby być zawodowym tłumaczem, ale ani sama filologia, ani sama wiedza z danej dziedziny nie wystarczy, żeby tłumaczyć teksty z tej dziedziny, bo filologom brakuje solidnego wykształcenia i zrozumienia tego, co tłumaczą. Wydaje im się często, że wystarczy płynąć po powierzchni tekstu, rozumieć znaczenie zdania i jakoś matematycznie jeden do jednego oddać znaczenie słów, posługując się przy tym słownikiem. Natomiast inżynierowie produkują ułomne zdania i też wydaje im się, że to wystarczy, bo przecież każdy to ich zdaniem zrozumie. A język ojczysty nie jest tak istotny. Ważne, żeby się 
formułki i równania zgadzały. W zależności od tego, jaki jest skład grupy, przy pracy z każdą z nich czeka nas solidne zadanie ujednolicenia tej wiedzy i wypracowanie na koniec każdego rocznika pewnych dobrych praktyk, doprowadzenia do tego, żeby uświadomić filologom, że nie wystarczy tylko, że przez pięć lat nauczyli się języka na bardzo dobrym poziomie, ale teraz muszą zdać sobie sprawę, w jakiej dziedzinie chcą się specjalizować i przede wszystkim zacząć się w niej specjalizować. Przestać myśleć, że jak znają już język, to mogą wziąć na warsztat każdą dziedzinę od medycyny po chemię, tłumaczenie literatury i w ogóle wszystko, tylko wybrać sobie wąski przedział i zacząć się w tym specjalizować, a panom chemikom trzeba uświadomić, żeby zaczęli się uczyć języka polskiego i języka obcego.

AG: I to najlepszy moment, żeby przejść do podsumowania naszej debaty. Poproszę o to Panią Joannę Marię Spychałę.

JMS: Cóż mi tutaj pozostało, jak tylko zgodzić się z moimi przedmówczyniami. Myślę, że to, na co jeszcze warto zwrócić uwagę, to to, że mamy tutaj nie tylko taką dychotomię, którą na każdym kroku podkreślamy, że z jednej strony są te kompetencje filologiczne, a z drugiej te dziedzinowe, i że jedni i drudzy muszą uzupełnić te umiejętności, których nawzajem im brakuje, bo powiedziałabym, że tutaj mamy trzy grupy kompetencji: jest to po pierwsze kwestia znakomitej znajomości języka, i to nie tylko języka obcego, ale też ojczystego, który często bywa zaniedbywany w toku studiów filologicznych, gdzie za bardzo skupiamy się na języku docelowym, a gdzieś ten polski jest traktowany po macoszemu; po wtóre jest wiedza specjalistyczna, o której dużo tutaj mówiliśmy, ale są też, po trzecie, kompetencje tłumaczeniowe, czyli coś, co jest, moim zdaniem, jeszcze odrębną grupą umiejętności i to jest to, co miałam na myśli mówiąc, że studia filologicznie niekoniecznie przygotowują do zawodu tłumacza. Niewątpliwie dają znajomość języka, dają znajomość kontekstu kulturowego, w jakim ten język funkcjonuje, do tego dochodzi wiedza językoznawcza, natomiast kompetencje tłumaczeniowe to jest bardzo konkretny zbiór technik, strategii, umiejętności. To widać zwłaszcza w przypadku tłumaczenia ustnego. Bardzo trudno jest wejść do kabiny, nie poznawszy zasad tłumaczenia symultanicznego, ale to widać również w innych kontekstach tłumaczeniowych: w tłumaczeniu pisemnym, w bardzo różnych miejscach. Więc te trzy komponenty muszą występować razem, do tego dochodzi znajomość języka ojczystego.

AG: Bardzo dziękuję. I bardzo poprosimy Panią profesor Matulewską o odniesienie się.

AM: Pozwolę sobie sparafrazować Monę Baker, bardzo znaną tłumaczkę, która mówiąc o kwalifikacjach idealnego tłumacza, stwierdziła, że właściwie 
najlepszym kandydatem na tłumacza jest dziecko dyplomaty, które nauczy się dwóch języków, chodząc do szkoły podstawowej w kraju ojczystym, potem wyjeżdżając z rodzicami gdzieś za granicę, tam nabywając kompetencje w zakresie języka obcego, następnie powróci do kraju ojczystego i tam skończy studia w zakresie jakiejś konkretnej dziedziny, po czym znowu wyjedzie za granicę, skończy kolejne studia, tym razem już za granicą, w tejże dziedzinie i po ukończeniu kolejnych studiów podyplomowych w zakresie tłumaczenia, gdzieś w okolicach 45. roku życia, zacznie myśleć o wykonywaniu zawodu tłumacza. To tak anegdotycznie, ale tłumacza musi przede wszystkim charakteryzować duża dociekliwość i chęć nieustannego samokształcenia, pewien głód wiedzy. Jeżeli tłumacz takich predyspozycji nie ma, czy też kandydat na tłumacza takich predyspozycji nie ma, nie ma również samokrytycznego podejścia do tego, co produkuje i do swoich braków w wiedzy, z całą pewnością nie będzie mógł tego zawodu wykonywać w sposób fachowy i nie będzie widział konieczności uzupełniania wspomnianych braków wiedzy. Każda dziedzina się przecież zmienia, każda dziedzina się starzeje, co chwilę zachodzą zmiany terminologiczne. To, że raz się nauczyliśmy, że ekwiwalentem terminu A w języku 1 jest termin $\mathrm{X}$ w języku 2, wcale nie oznacza, że za 5 lat dalej tak będzie.

AG: Dziękujemy. Ja bym wyrażał nadzieję, że studia filologiczne przynajmniej sprzyjają pozyskiwaniu kompetencji, które później okazują się ważne w wykonywaniu zawodu tłumacza - niech by tak pozostało. Wiemy, że jest to też pewien rodzaj talentu, charyzmy czasami, wykonywanie tego zawodu, realizowanie go i niezależnie od tego, co człowiek ukończył, jakie studia odbył, gdzie pozyskał tę wiedzę, to jest istotne, aby z niego to wypływało, taka umiejętność wrodzona niemalże. Tym samym dotarliśmy do końca naszej debaty. Taka refleksja mi się nasuwa, że wszystko jest w naszych rękach, przede wszystkim w rękach takich ekspertów-praktyków, jakich mieliśmy okazję tutaj wysłuchać. Podsumowując, zdołaliśmy porozmawiać o perspektywie rozdzielenia kompetencji tłumacza, jak i dalszego ich scalania, celowości i możliwości form zrzeszania się w Polsce tłumaczy oraz płynących z tego korzyści i wreszcie na temat perspektyw związanych $\mathrm{z}$ kształceniem tłumaczy - $\mathrm{w}$ tym ujęciu, który zakłada łączenie różnych kompetencji, bo myśląc o filologu-lingwiście, kimś, kto podejmuje studia w tym zakresie, trudno sobie wyobrazić, że będzie się posługiwał tylko językiem mówionym albo tylko językiem pisanym. W każdym razie wiemy, że i takie sytuacje mają miejsce. Chciałbym bardzo serdecznie podziękować Paniom za udział w tej debacie. Zapowiadam jej upublicznienie, na co mamy zgodę Pań. Wyrażam nadzieję, że treści w niej poruszone przyczynią się do podwyższenia poziomu kształcenia tłumaczy w Polsce, a opinie przez Panie wygłoszone posłużą jako wskazówki do praktycznego wykorzystania w kontekście dydaktycznym w pracy z adeptami sztuki tłumaczeniowej. Jeszcze raz Paniom dziękuję i tym samym zamykam naszą debatę. Do widzenia! 